\title{
Finding the Collective in an Era of Pension Individualization
}

\author{
From Adam D. Dixon ${ }^{1}$
}

\begin{abstract}
Many scholars approach pension restructuring in terms of neoliberalism and class conflict, suggesting that pension restructuring is reducible to a linear and one-dimensional process. This article argues that this limits the scope for understanding pension restructuring and thus limits our capacity to understand and uncover new possibilities and collective solutions, albeit capitalized solutions. This article attempts to enrich our understanding of pension restructuring by approaching it through the lens of reflexive modernization, or second modernity, where the institutions of first modernity undergo modernization themselves and where strict boundary demarcations are eroded. The article then theorizes the prospects of a collective resurgence in pension provision utilizing neoinstitutionalist theories of institutional design in conjunction with a case study of a new multiemployer German pension scheme. Ultimately, it is argued that past institutional legacies can be maneuvered to produce a collective response to the liberalized and market-oriented environment of pension provision, suggesting that individualization has limits.
\end{abstract}

\section{Introduction}

In recent decades finance and the prospects and risks it holds, has become one of the most salient features of contemporary capitalism. The production-led industrial economies developed in post-WWII decades have transformed or are quickly transforming to finance-led economies. The multifarious processes of globalization have contributed, among other things, to the breakdown or metamorphosis of traditional post-war socio-institutional structures from the nation-state to the firm to the family. Once seemingly stable socio-institutional loyalties and responsibilities have become unsettled. In this process, the individual has had to assume more and more responsibility for his / her life-cycle risks. This is increasingly visible in the area of pensions. State benefits have been cut and firms are increasingly reluctant to guarantee a final salary pension at retirement, as the costs of demographic ageing loom large. Unfortunately, pension individualization is no panacea for the problem of demographic ageing. Individual pension decision-making capacity under risk and uncertainty is suspect (Clark / Strauss 2008; Clark / Knox-Hayes 2007; Munnell / Sunden 2004; Strauss 2008) and individual pension provision is less cost-effective than collective provision as seemingly minor differences compound overtime to significant effect (Bateman / Mitchell 2004; Bikker / de Dreu 2009; Clark 2008).

For some pension individualization is just another case of neoliberalism or class conflict (e.g. Blackburn 2002; Blackburn 2006 a; Cutler / Waine 2001; Engelen 2003; Hacker 2006; Harmes 2001; Harmes 1998; Langley 2004; Langley 2006; Minns 2001). This nearly exclusive focus on neoliberalism and class conflict constricts them to seemingly linear and binary views of socioeconomic institutions. Institutions such as the nation-state, the firm, and the 'worker' are frequently approached with logics of non-ambiguity and strict differentiation. For example, Langley (2006: 920), owing pension individualization to neoliberal governmentality, ${ }^{2}$ states that, "the move from DB to DC has served to erode and ultimately to rupture the relatively

1 The author would like to thank Andrew Barry, Gordon Clark, Ewald Engelen, Ashby Monk and VillePekka Sorsa for helpful comments. The author would also like to thank Rob Bauer and the University of Maastricht for facilitating a visiting research position. Support for research was provided through an Oxford University Scatcherd European Scholarship. None of the above should be held responsible for errors, omissions or any opinions expressed herein.

2 For similar governmentality approaches to risk see also (Ericson / Doyle 2004; Ericson et al. 2000; O’Malley 2004).

Soziale Welt 60 (2009), S. $47-62$ 
settled postwar arrangements which had forged a network of investment relationships between the majority of workers". This may lead some to believe a return to the 'settled' structures of the past is possible through a purging of the neoliberal governmentality. Yet, the post-war development of occupational defined benefit (DB) pensions was inherently linked to the development of the large vertically integrated industrial conglomerate (Sass 2006). Today's firms on the other hand embody numerous forms and possess different financial resources and uncertain life-cycles. In other words, the institution that housed the DB pension has itself changed thus placing the settled relationship and appropriateness-of-fit of the DB pension with the modern firm in question (Monk 2008).

In first part of this article I argue, then, that pension restructuring and the individualization of risk and responsibility should be approached with more nuanced and non-linear conceptions of socioeconomic institutions and organizations. I develop this argument utilizing Ulrich Beck's theory of reflexive modernization and its more recent reformulation following the idea that we have moved into second modernity characterized by a non-linear blend of agency / structure, ambiguous boundary logics and a logic of institutional action that has shifted from an 'either / or' principle to a 'both / and' principle. I then consider, in a slightly stylized though empirically based manner, the nation-state and demography and the firm and final salary (DB) pensions in relation to pension restructuring in second modernity. Here I must add a disclaimer that this article is not about proving Beck's theory as historical fact or pitting his work against other modernization theories. Rather, Beck's work is used first and foremost as a mode of thinking through and framing the issues and a means of remaining sensitive to specific and potentially persistent factors such as geography, politics, culture, and institutions in changing spatiotemporal contexts.

This conceptual grounding sets the stage for the underlying question of this article. Is collective action possible in an era of pension individualization, and, if so, how and under what conditions? Or, should we believe commentators such as Bauman (2006: 21), who states that "the conditions of individualized society are inhospitable to solidary action; they militate against seeing the forest behind the trees"? In the second part of this article I address these questions by developing a parsimonious theory of potential collective resurgence utilizing neoinstitutionalist theories of institutional change and path generation, in particular the work of Campbell (2004). This theory argues that collective institutions of one spatiotemporal context can be maneuvered or employed in the design of new institutions to provide, or at least attempt to provide, collective solutions to problems in another. This theory is then applied empirically to a case study of MetallRente, a new and rapidly expanding pension scheme for Germany's metalworking and engineering sector which has garnered more than 250,000 contracts since its creation in 2001 through a partnership between Germany's largest trade union $I G$ Metall and the employers' association Gesamtmetall - ostensibly two organizations that epitomized the inner workings of Modell Deutschland during its zenith in the decades following WWII.

It would be misleading, however, to assume that others critical of pension individualization are not compelled to find solutions divergent from the structures of the past. Blackburn (2006 b), for instance, makes the case for universal, prefunded secondary pensions to be managed by networks of noncommercial regional social funds funded through an annual share levy of ten percent on corporations' profits. Though Blackburn should be commended for his visionary efforts and thought-provoking stance given the challenges that lay ahead, the likelihood of this proposal becoming a reality is doubtful. Historical-geographical conditions and political resistance would likely limit the implementation of an untested ahistorical-geographical institution. The goal of this two part exposition is thus to avoid the realm of impossibility and instead make a case for understanding and finding real actually occurring possi- 
bilities and latent potentialities given the conditions of transformed spatiotemporal contexts and the importance of history, geography, politics and culture in institutional design. Though a tall order, this may provide a more feasible means of finding sources of renewed solidarities.

\section{From one spatiotemporal context to another}

The basic premise of reflexive modernization theory is that the institutions of modern society itself are modernized as the taken-for-granted premises of modernity such as the primacy of the nation-state or the nuclear family are called into question, and are ultimately faced with the specter of renegotiation and renovation as contexts and contingencies change. Put another way, the social institutions, in which the coordinates of social change are grounded, are themselves transformed or are facing transformation. As such, this transformation places ever greater pressure on the certitudes of social and scientific knowledge and the authority of 'certainty' in general (Beck 1986; Beck et al. 1994; Giddens 1990, 1991). Put slightly differently, reflexive modernization theory assumes the existence of non-linearity and complex systems, systems that do not reproduce or are held in operational stasis but rather change (Lash 2003).

Recently, Beck, Bonß and Lau (2003) and Beck and Lau (2005) have refined reflexive modernization theory, re-characterizing it as second modernity with an explicit goal of reorienting the social sciences away from its god's-eye point of view position of first modernity to instead focus on discovering and explicating the new social and institutional forms that are taking the place of the certainties, distinctions and dichotomies of new spatiotemporal contexts. However proving the historical shift this implies as empirical reality is difficult to impossible, as Latour argues (2003), given the variety of definitions for 'modernity' or whether we have ever been modern. Yet as I see it, the salience of this approach, and its use in analyzing pension restructuring and the challenges in deriving collective solutions, lies in its capacity to explicate broader social change between differing spatiotemporal contexts. This can be done without adhering to the theory's larger and more epochal 'grand narrative-like' claim. In other words, the word 'modernity' can simply be used as another word for 'spatiotemporal context'.

Following Beck et al., there are six main premises of first modernity which describe the "explicit or implicit assumptions expressed in the actions and self-understanding of citizens, the goals of politics and the routines of social institutions" (Beck et al. 2003: 4). Firstly, first modernity society is a nation-state society in which social relations are contained predominantly in the territorial boundaries of the nation-state and most institutions maintain proximate relations with the nation-state. Secondly, first modernity societies are characterized by institutionalized individualism in which individuals are theoretically free and equal, but where this freedom and equality is patterned and constrained by social institutions such as a stable family structure. Thirdly, these are full employment societies, where status, consumption and social security are direct products of participation in the economy. Fourthly, nature is apart from society and is seen for its exploitative possibilities. Fifthly, first modernity societies develop on the basis of rational progress where it is anticipated that science is ultimately capable of demystifying and controlling nature. Finally, development is managed on the principle of functional differentiation in which progressive specialization is seen as a mode of constant improvement.

What these six premises underline is the linear and binary systems logic of first modernity. This is a system ordered by dichotomies, dualisms, and transparent boundary demarcations, a system of mutual confirmation and support between institutions. Knowledge and different forms of social and institutional organization are subject to an 'either / or' principle, such as organization or the market, family or not family. This principle permanently separates these different spheres and prevents ambiguity in the allocation of responsibilities, tasks and obligations. Different institutions have different responsibilities effectively freeing another insti- 
tution or social grouping from responsibility. In this bordered world, it is possible to recognize the difference between national relations and international relations, or work life from home life, for instance. From this punctilious and unambiguous ordering of social structures, rational decisions can be made and without limit. In other words, this ordering provides a system of action logics and rational solutions (Beck / Lau 2005).

In second modernity the social ordering of first modernity is no longer exempt a priori from the processes of modernization. The institutions which comprise its foundation lose their legitimacy or become markedly altered. This leads to instability and uncertainty. For instance, economic, political and cultural globalization undermines the primacy and economic and social management competences of the nation-state. Technological innovation, global production and flexible labor practices undermine the stability of the full employment economy and its social reproductive capacities associated with the Fordist firm and its developed labor-management institutions. The nature and meaning of 'work' in social reproduction loses its foundation (Beck 2000). At the same time, the welfare state and its inherent bias towards the individual and the demystification of gender roles both in work and in the family intensify individualization (Beck / Beck-Gernsheim 2001). Ultimately for all, these changes are products of modernization itself.

Unlike first modernity, the either / or principle becomes eclipsed by the both / and principle, such as nature and society, war and peace, organization and market, family and work. Whereas before decisions could be made based on simple dichotomies, dualisms and standardized expectations of responsibility and authority, the blurring of the boundaries between institutions and the resulting ambiguity this places on responsibility and task allocation impairs decisionmaking. This then contributes to the increasing demystification and delegitimization of social structures as these no longer effectively produce cogent or satisfactory responses and solutions. What follows then from the limits of first modernity social ordering and categorization is a system of boundary management. This is a system of pragmatic renegotiation in which plural boundary demarcations replace the previously unambiguous dualities and standard forms. Social organization adapts to uncertainty as the logic of non-ambiguity and strict differentiation reaches their limits and thus limits the capacity of institutions to provide unquestionable certainty (Beck / Lau 2005).

Two main conclusions result from the change from first to second modernity, or rather the change from one spatiotemporal context to another. Firstly, the institutions and socio-economic organizational patterns of first modernity can no longer be expected to reproduce the same effects and benefits they once did. They themselves have become unsettled, thus undermining the mutual confirmation and support they once provided each other. For example, the entry of women into the workforce in the last three to four decades and the appearance of diversiform family structures have unsettled the artificial gender roles provided by the nuclear singleincome family. Who cooks, cleans and raises the children and who pays the bills? This relates then to the second conclusion that certainty is no longer certain. Certainty becomes, then, more and more contingent. As certainty can no longer be reached, certainty becomes rather the relative stability produced by dynamic rebalancing vis-à-vis shifting contingencies and changing contexts.

\section{Pensions and shifting contexts}

\section{The nation-state and demography}

There has been considerable research conducted on the factors behind the establishment and expansion of public pension systems and what explains the parametric differences between countries (Baldwin 1990; Esping-Andersen 1990). What is fundamental for this article, howe- 
ver, is that there is a noticeably close relationship between public pension expansion and the coming of age and expanding dominance of the nation-state form of political-economic organization beginning towards the end of the $19^{\text {th }}$ century and continuing through most of the $20^{\text {th }}$. Hence, the beginnings of social insurance legislation in Germany in the latter part of the $19^{\text {th }}$ century, for instance, coincided with the development of the German state following unification in 1871 and the rise of German industrial power during the Second Industrial Revolution.

At the apex of expansion of state-based pension provision following WWII, nation-states maintained considerable control and influence over their economies (Galbraith 1967; Shonfield 1965). Fixed exchange rates and limited global economic flows meant that nation-states and central banks could engage fiscal and monetary policy to stimulate economic growth. In addition, through much of the $20^{\text {th }}$ century the global economic system was more of an international system rather than a globalized system (Hirst / Thompson 1999). In other words, the national sphere was relatively separate from the international sphere. Events occurring in the international sphere did not necessarily cause an equal effect in the national sphere, or at least policy instruments existed to cope with them. Given this separation, a more effective 'Keynesian' national level governance of the economy produced high-levels of labor force participation and high economic growth reaching an apex in the thirty years following WWII. Equally crucial to this dynamic was rapid population expansion, which kept the dependency ratio of workers to retirees low. In effect, the context of population growth and high economic growth kept the public PAYG pension liabilities to a minimum (Ogawa / Takayama 2006).

However, following the collapse of the Bretton Woods system of fixed exchange rates in the $1970 \mathrm{~s}$ and the expansion of global economic integration facilitated through free-trade agreements and regional trading blocs, nation-states began to lose the political-economic policy tools they once had. Compounding this, advancing technology and new means of financing firms began to unsettle the economic growth producing capacity of the postwar production economy (see following section). In Europe, for example, Eurozone countries are now subject to strict budgetary requirements and have lost control over monetary policy in addition to being subject to more competitive production markets. This has limited these countries' abilities to reach full-employment and produce high economic growth through policy means and coordination of the production economy. Adding to this changing context, many countries, especially those in Europe, have experienced a considerable slowdown in population growth and a subsequent ageing of the population causing an increase in dependency ratios. For many advanced political economies, then, the persistence of low economic growth rates compared to postWWII levels, lower levels of labor-force participation and increasing numbers of retirees have put the economic viability and future stability of public PAYG pension provision in question. This situation has provided much of the logic for public pension reform (Arza / Kohli 2008; Clark 2003; Schludi 2005).

Here we see the emergence of the tension or interplay between first and second modernity. In first modernity the nation-state had more control over the political-economic governance within its border. Moreover, this was a period of demographic expansion. From a functionalist perspective then, the economic governance tools available to the nation-state accompanied by favorable demographic conditions provided stability to public PAYG pension systems. In second modernity, the nation-state does not have the same economic governance capacities or spatial structure, and the demographic situation has changed. The nation-state could, for example, fund the increasing pension liabilities through increased fiscal measures, though this would likely trigger an erosion of the nation-state's economic position and cause revolt in sovereign bond markets as the nation-state's capacity to fulfill its debt obligations becomes increasingly uncertain. 
The implication here is that what functioned for first modernity, when nation-state politicaleconomic borders were less porous and demographic conditions were different, is not certain to function in the shifting and ambiguous boundaries of second modernity. This does not mean that the nation-state ceases and desists in second modernity; rather, its role is reformulated to account for changing contexts and different contingencies (Dixon 2008). Hence, we see the search for new solutions around a public / private divide that recognizes the limitations, both economic and demographic, now facing the nation-state (Clark / Whiteside 2003).

\section{The firm and final salary $(D B)$ pensions}

In the immediate decades following WWII two approaches to expanding pension coverage were taken by the advanced political economies. Most continental European countries opted to expand state-based and quasi-public provision (Whiteside 2006), whereas most Anglo-Saxon countries, the US, the UK, Australia and Canada, opted for an expansion of corporatesponsored DB plans. The pension liability was thus firmly placed in the realm of responsibility of the firm, as amplified in recent survey findings (Clark / Monk 2008). The firm was therefore the socioeconomic institution which would guarantee the DB pension, another socioeconomic institution. For instance, private sector employer plan coverage in the US expanded from barely 15 percent of the private workforce in the beginning of the $1940 \mathrm{~s}$ to almost 40 percent by 1960 . Key to this expansion was the growth of large postwar industrial firms, a strong labor movement driving collectively negotiated plans and considerable tax advantages for pensions as deferred compensation (Sass 2006). As such, the final salary pension grew during the zenith of postwar managerial capitalism, a period when large industrial firms in conjunction with national planning and macroeconomic governance were thought to be capable of providing long-term economic growth and minimize unpredictable negative effects to social welfare institutions, e.g. corporate-sponsored DB pensions (Clark 2005 a; Cutler / Waine 2001; Jacoby 1997).

The prototypical firm of managerial capitalism was characterized as containing a set of distinct operating units controlled by a hierarchical system of salaried managers. This firm brought various units of diverse economic activities under its control. Through the vertical integration of distribution and supplier networks, managers could assure the correct amount of throughput in order to sustain the firm's productivity. Likewise, firms consolidated through horizontal combination, increasing a firm's capacity to anticipate prices. With a breadth of economic activities available to the firm along with the firm's large size, the hierarchical organization of managers was able to monitor and coordinate the transactions and interactions between the various activities of the firm instead of the market mechanism (Chandler 1977; Williamson 1981). It was out of this corporate form that the DB pension as a labor-management tool, as part of managing the internal labor market of the firm, was employed and thought to be sustainable.

Over the last three decades however, the environment in which the modern firm operates has changed substantially. Implicated in this change is the sustainability and coverage of corporate-sponsored DB pensions. On one side there has been the rise in prominence of financial markets and new investment opportunities, on the other globalization, trade liberalisation, and increased sophistication of production and product markets (Jensen 1993). Financial markets have gone from relatively passive spectators to active participants in everyday corporate life, pricing past and future commitments against competing market opportunities (Clark 2005 b). Trade liberalization, selective consumer tastes, low-cost labor from the developing world and improvements in technology have forced the rationalization of industrial production and development everywhere. At the same time, international accounting standards have become more sensitive to firms' DB pension liabilities and the effects of demographic ageing and have moved to mark-to-market, or fair value accounting, increasing the transparency of pension 
accounting and thus placing them under greater market scrutiny and time-sensitivity (Biondi / Suzuki 2007; Clark / Monk 2007).

Rewarded in markets are firms with new structures that encourage dynamism and flexibility at the expense of old firms with inflexible constructs and commitments. This new environment has significantly altered and constrained the operational and financial capabilities of firms resulting in new corporate form and function (Rajan / Zingales 2001; Zingales 2000). As such, many firms are no longer willing to saddle potentially costly long-term and uncertain commitments such as DB pension plans for fear these may compromise the firm's competitiveness and long-term survival (Monk 2008).

Like the changing boundaries and capacities of the nation-state, the changing nature of the modern firm and the competitive context in which it operates has altered its capacity to provide and sustain final salary pensions. Again we see the tension between first and second modernity. In first modernity the firm assumed the role of pension provider. This responsibility came in addition to its primary role as an employment institution and producer of goods. In second modernity the firm, in its variety of forms, is faced with rapid competition from foreign rivals and new ventures, quickly changing consumer tastes, and financial markets that will judge its capacity to meet its promised commitments. The internal labor markets that supported the DB pension are being eroded (Schmid 2006) and the increasing frequency of non-linear career patterns, job mobility and changing job structures are challenging the old form of occupational pension provision (Engelen 2006).

Thus as the firm itself and the contexts in which it operates changes, the capacities of the firm change and become uncertain in both spatial and temporal terms. As Nigel Thrift saliently puts it, "capitalist firms may be able to mobilize power and enrol allies but they are as uncertain about the future as we all are because the future unfolds as a virtuality - it is continually creating temporary actualizations out of new questions - not a known quantity, or at least a distinct possibility. So capitalist firms may sit on the bridge of the world, able at their best attempts to steer it in certain directions, but they still cannot know what is around the corner" (Thrift 2005: 4). Hence, the reluctance of many 'new' economy firms to provide final salary pensions and why many 'old' economy firms are closing them (Monk 2008). Ultimately, in second modernity questions arise whether the individual firm and pension provision match or if another institution is more capable of managing new uncertainties and shifting contexts, such as an independent industry-wide pension scheme.

\section{Theorizing the resurgence of collective institutions}

Starting from the comparative political economy of pension reform and pension provision we know, on the one hand, that inherited institutional settings, e.g. entrenched interest groups, and variation in programmatic design of pension provision systems across countries, e.g. 'Bismarckian' vs. 'Beveridgian', constrain policy makers' capacities to reform pension systems. As such, pension reform follows different paths and does not guarantee convergence to a uniform outcome of pension provision across countries (Myles / Pierson 2001). Indeed, as has been noted, pension reform is leading to new compromises along different public / private divides, where state-based provision and collective organizations remain a vital component of the system (Clark / Whiteside 2003).

On the other hand, we know that the history of pension provision in the latter half of the $20^{\text {th }}$ century was dominated by collective provision, whether public or private, funded or unfunded (Whiteside 2006). If pension reform is subject to path dependencies, then it is equally viable that collective provision is subject to path dependencies and persistence as the two are inherently related. In other words, collective organizations and the associated routines of 
collective provision cannot necessarily be expected to quickly dissolve in the face of increasing individualization and liberalization. Likewise, it is possible to assume that collective organizations and / or collective modes of coordination are capable of adaptation, renewal and redeployment in a more liberalized environment, an environment where pension provision comes increasingly to terms with global finance. We can refine this process by looking at neoinstitutionalist theories of institutional change.

Recently, neoinstitutionalist theories of change have been building on the understanding of institutions as resources. In previous accounts of institutional change, institutions were viewed primarily as constraints on actors' behavior and their capacity for innovation. Hence, the difficulties surrounding pension reform. Viewing institutions as resources as well as constraints, institutions can provide actors with established routines, principles and opportunities with which they can use to innovate and generate new solutions. In this case, innovation is constrained innovation as actors are never completely free of the constraints imposed on them by institutions. This allows for a more nuanced and less deterministic use of path-dependency, though still theoretically robust, where context and history matter but where deviations and manipulation of the path occur to generate new paths or kinks in the current path. Said differently, structure and agency come together jointly to condition the path. In addition, this research has become more sensitive to globalization, recognizing the limits of static typologies and conceptions of political economies and institutions as closed systems. Here, multiple paths at various scales interact to condition each other (Campbell 2004; Crouch 2005; Djelic / Quack 2007; see also Streeck / Thelen, 2005).

Yet if we are to understand more thoroughly the possibility of collective resurgence within a context of liberalization, we must also have a more complete understanding of the different mechanisms involved in institutional change. Though multiple mechanisms exist, Campbell (2004) underscores two important mechanisms in particular, bricolage and translation, which explain institutional innovation at the local level and the diffusion of processes and practices from other scales. Through the mechanism of bricolage actors recombine elements of the established / past local institutional repertoire to create new but seemingly similar institutions to cope with new problems. We can refine the mechanism of bricolage further by dividing it into two forms. The first form, substantive bricolage, is when actors recombine existing institutional elements to achieve substantive goals, such as increasing market share, reducing transaction costs, or managing labor relations. The second form, symbolic bricolage, is a process whereby actors attempt to achieve acceptance and legitimacy in the broader social environment through a recombination of culturally specific symbolic practices and principles (Campbell 2004: $69 \mathrm{f}$ ).

The mechanism of translation is similar to bricolage, but instead of describing how local assets can be recombined to produce innovative solutions translation describes the process by which ideas and institutional practices from the global level or another adjacent institutional field provide actors with a source for institutional innovation. Here, externally given elements can be combined with local elements inherited from the past, thus providing a source of change. But like translating from another language, translation of institutional elements from a nonlocal field implies that application and enactment will differ depending on the local context (Campbell 2004: 79 f). By this logic, seemingly obsolete collective institutions can be redesigned using ideas and practices from an outside institutional field. At the same time, translation provides a link between institutional levels, such as global finance and labor relations. 


\section{Forging a collective response in second modernity: MetallRente ${ }^{3}$}

With pronounced demographic ageing and persistently difficult economic conditions weighing on the viability of the public pension system, Germany enacted an important pension reform in 2001. Two main features characterize the reform. Firstly, the public liability was reduced. A pensioner fulfilling the standard requirements, e.g. maximum number of working years, will now receive an income replacement of 64 percent by 2030 in place of the pre-reform income replacement level of 70 percent. Secondly, tax subsidies were enacted for different types of private pensions. Instead of private pensions being supplemental to the public pension, they are now substitutes for the decrease of the public pension. In addition, the 2001 pension reform granted employees the right to convert a tax-deductible 4 percent of earnings into private pension contributions and, at the behest of labor unions, to negotiate this under a collective agreement. In this case employers are obliged to provide at least one type of occupational pension provision. Furthermore, the reform introduced 'pension funds' with limited investment restrictions following the prudent person rule as a new funding vehicle to provide yet another option for private pension development. Considering the scope of the parametric reform and development of measures to increase private pension savings, the 2001 reform can be seen as a paradigm shift in German pension provision (Schmähl 2003).

The 2001 reform renegotiated the public / private divide, but it did not mandate what the private side of the divide would look like. Instead of granting exclusive rights to any particular organization in providing pensions, the reform created a competitive market-oriented environment. In this system future pensioners voluntarily choose a pension provider to substitute retirement income from the reduced public pension, or choose nothing at all. Insurance companies, asset managers and industry-wide occupational pension schemes must compete in the market for clients. No single provider has a mandated right to provide services in place of another provider outside of the market. However, this does not preclude firms from managing their own pension schemes as many large firms do. In response to this new public / private regime, Germany's largest labor union IG Metall and the German employers' association for the metalworking and engineering industry Gesamtmetall made a joint declaration to establish an industrial multi-employer pension scheme for the metal working industry in September 2001. In October 2001, MetallRente, a non-profit independent organization jointly governed by the social partners, was founded and began operations in January 2002.

Since its inception in 2002 MetallRente has garnered a considerable share of the total deferred compensation market in Germany with roughly 13,000 companies offering MetallRente pension plans with contracts covering roughly 250,000 employees, making it a major market player. Indeed, MetallRente has become an industry standard for multi-employer pension schemes in Germany and even derives over 50 percent of its clients from employers and employees not covered under the collective agreement in the metalworking and engineering sector, as well as other industrial sectors such as textiles. As is suggested by this rapid success, MetallRente and the model of collective provision it espouses is likely to evolve considerably. Consequently, MetallRente can be seen as an influential case (see Gerring 2007) vis-à-vis collective resurgence.

The fundamental goals of MetallRente are twofold. For employers, MetallRente provides an efficient supply of pension plan options with low administrative costs that are in compliance with the collective agreement. This allows employers to fulfill their obligations under the

3 Information pertaining to MetallRente was gathered through interviews conducted in Berlin, Germany, January $28^{\text {th }}$ till $30^{\text {th }} 2008$. Though much of the information is publicly available and not sensitive, I still follow the accepted practice in economic geography of 'close dialogue' and maintain interviewees' confidentiality (Clark 1998). 
collective agreement while focusing their resources on their core business areas instead of expending resources on pension administration - a separate area of expertise. For employees, the goal of MetallRente is to provide a competitive price on policies and generate an above average premium on savings through the capacity to exert collective leverage over the market.

Operating in a competitive and voluntary environment, the design of MetallRente takes into consideration both the demands of providing a pension product, e.g. insurance and asset management expertise, and the sales and marketing tasks necessary to acquire new clients (employers and employees) and compete with other providers. The social partners cannot simply force their members to accept MetallRente products as it is both voluntary to employers and employees. To solve this problem MetallRente utilizes a consortium of eight of Germany's most well-known insurance / asset management companies led by the Allianz Group. The consortium members are tasked with marketing MetallRente to the approximately 18,300 companies and approximately 3.4 million employees in the target industry. Their relative success in acquiring new clients also partially determines the allocation of investment management, which is based on competitive contracts as well. This creates an environment of competition that MetallRente can leverage to extract the best service and lower costs from the consortium members for its clients.

In another effort to appear attractive to the market, MetallRente offers several types of pension vehicles for employers and employees to choose from, a Pensionskasse, Direktversicherung (direct insurance), and a Pensionsfond. Both the Pensionskasse and Direktversicherung are traditional German insurance products subject to stricter asset allocation and guarantees. These products are not new to the German market and were used extensively under the previous supplemental pension system. However, due to the guarantee they provide, they are likely to have a lower return. The Pensionsfond is an equity-oriented fund comparable to Anglo-American pension funds. The Pensionsfond is also 100 percent focused on socially responsible investment. Unlike the other two vehicles, the Pensionsfond can tap the full potential of both strategic long-term asset allocation (Campbell / Viceira 2002; Hoevenaars 2008) and the alleged equity premium of global financial markets (Fama / French 2002). Indeed, since inception the Pensionsfond has had the best investment performance of the three products. However, the Pensionsfond represents less than 10 percent of contracts. As was indicated to me in an interview, this is likely due to the novelty of the vehicle in comparison to the others, considering these have a longer track record in the German market and are thus better understood by employers and employees as well as the marketing teams. Over time, the Pensionsfond may increase proportionately more as the vehicle becomes more standard in the German market. Furthermore, MetallRente offers two types of plan designs for employers to choose from. The first is a defined benefit plan based on contributions with a guaranteed interest rate. The second is a defined contribution with a repayment guarantee on the nominal value of contributions. In effect, MetallRente provides hybrid plans that are neither traditional final salary nor pure defined contribution, thus providing some degree of risk-sharing.

In this effort at collective resurgence we see both processes of substantive bricolage and symbolic bricolage at work. The past is not simply a constraint, but rather a valuable resource. In terms of substantive bricolage we see how well established institutions of the old Modell Deutschland were utilized to provide a collective institutionalized solution in a newly liberalized environment. As key points in German labor relations, IG Metall and Gesamtmetall have a natural communicative relationship with their respective members. Given the 2001 reform allowed for pay conversion in the collective agreement, this provided a natural opportunity for the two organizations to become involved in pension provision and provide options for their members that are more attractive than the market. However, private pension provision is beyond the expertise and institutional capabilities of either of these institutions. In this case, 
building a pension provider from the ground up would likely have been impossible, not to mention that this new provider would have to be capable of competing on the market and would have to convince clients of its merits. As such, the local German insurance industry and its expertise were called into partnership to provide sales and marketing and financial services.

In terms of symbolic bricolage, IG Metall and Gestamtmetall are iconic symbols of German labor relations and have been so for much of modern German political-economic history provides a stronger sense of legitimacy to MetallRente. In this sense MetallRente symbolically maintains pension provision within the realm of work and labor relations while providing a financial service via global financial markets. This symbolism undoubtedly contributes to marketing efforts and gaining trust and recognition among new clients. One can assume that clients may prefer, in addition to the cost effectiveness of the scheme, to be associated with an institution dedicated to their industry and profession rather than a more distant insurance company. Nevertheless, the constitution of the consortium members also manifests symbolic bricolage. Members such as Allianz have long and visible histories in German financial services and the German industrial economy. Indeed, this provides another source of trust and legitimacy to MetallRente.

In terms of translation, the 2001 pension reform opened a closer link between the practices and prospects of global finance and German pension provision and the World Bank's (1994) three-pillar model. However, as the case of MetallRente demonstrates, the implementation of this link has been conditioned by and partially conformed to the local inherited environment. Inherited are the institutions and structures of the old coordinated market economy of Modell Deutschland. Many scholars argue that Modell Deutschland no longer functions as it once did and has been in decline for several decades. However, many of the institutions of Modell Deutschland still remain, such as national-level collective bargaining between labor unions and employers associations (Kitschelt / Streeck 2004). Through the creation of MetallRente, these inherited collective institutions provide a carrier for the prospects and practices of global finance. Yet, leveraging coordination and scale as the inherited institutions once did, this new institution serves as a friction on the assumed neoliberalizing / marketizing forces associated with global finance.

With regard to a second modernity or rather the different spatiotemporal context of the present, MetallRente comes to terms with both the altered and uncertain positions and responsibilities of the German state and the modern firm and subsequently the modern employee. In the case of the German state, MetallRente provides a collective institutional solution to the increased individualization and market-oriented environment following the 2001 pension reform. For firms, MetallRente provides a more cost-effective solution to pension provision, allowing firms to focus on their core activities thus adding to their competitiveness. For employees, the cost-effectiveness of MetallRente translates into a better deal than would be available on the open market to substitute the decrease in one's state pension. Moreover, MetallRente avoids the hazards of individual financial decision-making by providing standardized products and expert asset management.

Not surprisingly MetallRente embodies the both / and logic of second modernity. MetallRente is both in the market and outside the market in the sense that it must compete in the market but also capable of using leverage over the market. Ultimately, in MetallRente we see a solution that tries to come to terms with the shifting boundaries of second modernity. MetallRente does not provide the same certainty once thought capable in first modernity. Rather, MetallRente pools together resources from the past and attempts to provide an innovative and collective solution, a system of pragmatic boundary management, for the uncertainties of the future. In this way MetallRente recombines the forces of solidarity. 
Though I have categorized MetallRente as an influential case due to its rapid development and considering it is a partnership between two iconic symbols of German labor relations, I would like to finish this case by highlighting some other examples of collective resurgence in Germany as well as other political economies. For example, the labor union and employers' association for Germany's mining, chemical and energy sectors, $I G B C E$ and $B A V C$, founded ChemiePensionsfonds in April 2002. ${ }^{4}$ In France, to highlight another political economy, many collective non-profit organizations responsible for managing complementary PAYG pensions have started to offer their members capitalized pension products following the creation of new pension savings vehicles (the plan d'épargne retraite collectif and the plan d'épargne retraite populaire) in $2003 . .^{5}$ One such example is Pro BTP, the organization for the French construction sector founded in 1901, which possesses its own asset manager Gestion BTP for managing the investments of its various pension products. ${ }^{6}$ Though space limits but a brief mention, these examples indicate that collective resurgence can and does occur. A challenge for future research is to highlight more of these cases and to understand their constituent differences and similarities in terms of both substance and origin and their engagement with global financial markets.

\section{Conclusion: Recombinant solidarity in the labyrinth of solitude}

Recall this article began with two dilemmas facing the individualization of risk and responsibility from pension restructuring: the problems of individual financial decision-making and the efficiency of collective provision versus individual provision. The prognostications of some were then questioned for their nearly exclusive focus on neoliberalism and class conflict. The article then attempted to recast the debate through the lens of reflexive modernization and the interplay espoused between different spatiotemporal contexts - first versus second modernity - so as to provide a more nuanced and less reductionist understanding of modern institutions, in this case the nation-state and the firm, and the problems and contexts they now face. This was done not to necessarily disagree with the aforementioned arguments. Indeed, factors such as certain neoliberal discourses surrounding pension restructuring should be taken seriously. However, we should be skeptical of generalizing and reducing pension restructuring to such elements alone considering the challenges of changing institutional forms and the real problems posed by demographic ageing.

Implicit throughout this article was the understanding that the new context of the present (future) limits the response of institutions built for the problems, contexts and contingencies of the past. Can we expect, then, the subsequent restructuring processes of second modernity to necessarily entail a more individualized, atomized and lonely world? What are the solutions to the abovementioned dilemmas? Can we reignite social solidarity in the face of neoliberal individualization and where the individual is the basis of social reproduction? The modernization of modernity limits the stable bases from which we construct this narrative. How can we say that the nation-state is the proper nexus of social solidarity and thus the natural space for social welfare provision when the nation-state itself is undergoing considerable change? This is equally applicable to the modern firm and modern economies. Moreover, is the nationstate or the labor-relations system of the old industrial economies the only sources of solidarity?

It was suggested that reform of public pension provision is a form of reflexive modernization where the nation-state increasingly becomes part of a both / and logic. The nation-state is part

4 See www.chemiepensionsfonds.de.

5 An examination of the various complementary PAYG pension organizations under the ARRCOAGIRC organization via the www.agirc-arrco.fr website revealed that many of these organizations now provide capitalized pension products along with other services.

6 See www.probtp.com. 
of the both public and private solution to demographic change and more uncertain economic and political futures. For the firm and its multiplicity of forms, pension provision has increasingly come at odds with the new contexts and competitive pressures it faces. This suggests that solutions to occupational pension provision at the level of the firm must necessarily contain, 'and' firm competitiveness. That is, how can we involve firms in pension provision and in that respect risk-sharing without risking the firm's competitiveness, which if damaged would put the future of its role and capacity to provide any pension at all in question?

One important lesson to be taken from the case study of MetallRente is that collective solutions are possible. Here it was demonstrated that the collective institutions of the past are resources capable of engagement, through processes of bricolage and translation, in the search for collective solutions to the dilemmas of the present and thus the future. More importantly however, it was suggested that the most successful of these, and those likely to provide a more sustainable collective solution, are those that recognize the changed institutional context, e.g. demographic ageing and competitive economies, as MetallRente attempts to do. Another important lesson is that specific conditions for the resurrection / maintenance of social solidarity, i.e. geography, politics, culture and institutions, matter. The substantive and symbolic bricolage of the legacies of German industrial coordination and the translation of the prospects of global finance in the development of MetallRente implies that a degree of local / national specificity will likely remain. This also assumes that each political economy has a different degree of collective legacies to derive solutions from. The brief example of emerging forms of pension provision via collective institutions in France suggests that collective responses are feasible elsewhere. However, more research is needed to understand more completely the differences between collective responses in different political economies.

To be sure, neoliberal individualization has become a more salient feature of modern societies. Yet, does it blind us from seeing the forest behind the trees? This article cannot give a definitive answer to this question. Nevertheless, this article challenges the notion that neoliberalism and some of the forces associated with it such as global finance inevitably destroy the bonds of solidarity and our efforts to derive such solidarity. If we believe Bauman's pessimistic prognosis for society we are seemingly left without any hope. Yet fortunately Bauman's prognosis might be missing an important element of the human condition. For Octavio Paz (1950) solitude is the ultimate root of the human condition from which we cannot escape. Yet in this labyrinth of solitude a dialectic exists in which the individual is also in search of communion with the other. If we believe this, then perhaps a collective future is still possible. Yet achieving this will not come through lamenting the passing of an era. Nor will this likely arrive via some grand scheme such as the one proposed by Blackburn, even if we agree such 'big thinking' is needed. What is more likely, and of which researchers should seek out and attempt to understand, are the emerging pragmatic though possibly imperfect collective solutions that recognize and mold to the dynamically shifting boundaries and contingencies of contemporary socioeconomic contexts.

\section{References}

Arza, Camila / Martin Kohli (2008): Pension reform in Europe: Politics, policies and outcomes, London.

Baldwin, Peter (1990): The politics of social solidarity: Class bases of the European welfare state: 1875-1975, Cambridge.

Bateman, Hazel / Olivia Mitchell (2004): New evidence on pension plan design and administrative expenses: the Australian experience, in: Journal of Pension Economics and Finance 3, S. 63-76.

Bauman, Zymunt (2006): Liquid fear. Cambridge. 
Beck, Ulrich (1986): Risikogesellschaft: Auf dem Weg in eine andere Moderne, Frankfurt / Main.

Beck, Ulrich (2000): The brave new world of work, Cambridge.

Beck, Ulrich / Elisabeth Beck-Gernsheim (2001): Individualization: Institutionalized individualism and its social and political consequences, London.

Beck, Ulrich / Wolfgang Bonß / Christoph Lau (2003): The theory of reflexive modernization: problematic, hypotheses and research programme, in: Theory, Culture \& Society 20, S. 1-33.

Beck, Ulrich / Anthony Giddens / Scott Lash (1994): Reflexive modernization: Politics, tradition and aesthetics in the modern social order, Cambridge.

Beck, Ulrich / Christoph Lau (2005): Second modernity as a research agenda: theoretical and empirical explorations in the 'meta-change' of modern society, in: The British Journal of Sociology 56, S. 525-557.

Bikker, Jacob / Jan de Dreu (2007): Operating costs of pension funds: The impacts of scale, governance, and plan design, in: Journal of Pension Economics and Finance 8, S. 63-89.

Biondi, Yuri / Tomo Suzuki (2007): Socio-economic impacts of international accounting standards: an introduction, in: Socio-Economic Review 5, S. 585-602.

Blackburn, Robin (2002): Banking on death: Or, investing in life: the history and future of pensions, London.

Blackburn, Robin (2006 a): Age shock: how finance is failing us, New York.

Blackburn, Robin (2006 b): The global pension crisis: from gray capitalism to responsible accumulation, in: Politics \& Society 34, S. 135-186.

Campbell, John L. (2004): Institutional change and globalization, Oxford.

Campbell, John Y. / Luis M. Viceira (2002): Strategic asset allocation: portfolio choice for long-term investors, New York.

Chandler, Alfred D. (1977): The visible hand: the managerial revolution in American business, Cambridge.

Clark, Gordon L. (1998): Stylized facts and close dialogue: methodology in economic geography, in: Annals of the Association of American Geographers 88, S. 73-87.

Clark, Gordon L. (2003): European pensions \& global finance, Oxford.

Clark, Gordon L. (2005 a): Re-writing pension fund capitalism 1: The modern corporation and pension benefit system in a world of perpetual motion, in: Oxford University Centre for the Environment Working Papers G-05-09.

Clark, Gordon L. (2005 b): Money flows like mercury: the geography of global finance, in: Geografiska Annaler 87B, S. 99-112.

Clark, Gordon L. (2008): Governing finance: Global imperatives and the challenge of reconciling community representation with expertise, in: Economic Geography 84, S. 281-302.

Clark, Gordon L. / Ashby H. B. Monk (2007). The 'crisis' in defined benefit corporate pension liabilities part I: Scope of the problem, in: Pensions 12, S. 43-54.

Clark, Gordon L. / Ashby H. B. Monk (2008). Conceptualizing the defined benefit promise: Implications from a survey of expert opinion, in: Benefits Quarterly 24, S. 7-18.

Clark, Gordon L. / Janelle Knox-Hayes (2007): Mapping UK pension benefits and the intended purchase of annuities in the aftermath of the $1990 \mathrm{~s} \mathrm{stock}$ market bubble, in: Transactions of the Institute of British Geographers 32, S. 539-555.

Clark, Gordon L. / Kendra Strauss (2008): Individual pension-related risk propensities: the effects of sociodemographic characteristics and a spousal pension entitlement on risk attitudes, in: Ageing and Society 28 , S. 247-274.

Clark, Gordon L. / Whiteside Noel (Hrsg.) (2003): Pension security in the 21st century: redrawing the public-private debate, Oxford. 
Crouch, Colin (2005): Capitalist diversity and change: recombinant governance and institutional entrepreneurs, Oxford.

Cutler, Tony / Barbara Waine (2001). Social insecurity and the retreat from social democracy: Occupational welfare in the long boom and financialization, in: Review of International Political Economy 8, S. 96-118.

Dixon, Adam (2008): The rise of pension fund capitalism in Europe: an unseen revolution?, in: New Political Economy 13, S. 249-270.

Djelic, Marie-Laure / Sigrid Quack (2007): Overcoming path dependency: path generation in open systems, in: Theory and Society 36, S. 161-186.

Engelen, Ewald (2003): The logic of funding European pension restructuring and the dangers of financialisation, in: Environment and Planning A 35, S. 1357-1372.

Engelen, Ewald (2006). Changing work patterns and the reorganization of occupational pensions, in: Gordon L. Clark / Alicia H. Munnell / Michael Orszag (Hrsg.), Oxford handbook of pensions and retirement income, Oxford.

Ericson, Richard V. / Aaron Doyle (2004): Catastrophe risk, insurance and terrorism, in: Economy and Society 33, S. 135-173.

Ericson, Richard / Dean Barry / Aaron Doyle (2000): The moral hazards of neo-liberalism: lessons from the private insurance industry. Economy and Society 29, S. 532-558.

Esping-Andersen, Gøsta (1990): The three worlds of welfare capitalism, Cambridge: Polity.

Fama, Eugene F. / Kenneth R. French (2002): The equity premium, in: The Journal of Finance 57, S. 637-659.

Galbraith, John K. (1967): The new industrial state, London.

Gerring, John (2007): Case study research: principles and practices. Cambridge.

Giddens, Anthony (1990): The consequences of modernity, Cambridge.

Giddens, Anthony (1991): Modernity and self-identity: Self and society in the late modern age, Cambridge.

Hacker, Jacob S. (2006): The great risk shift: the assault on American jobs, families, health care and retirement and how you can fight back, Oxford.

Harmes, Adam (2001): Mass investment culture, in: New Left Review 9, S. 103-124.

Harmes, Adam (1998): Institutional investors and the reproduction of neoliberalism, in: Review of International Political Economy 5, S. 92-121.

Hirst, Paul Q. / Grahame Thompson (1999): Globalization in question: the international economy and the possibilities of governance, Cambridge.

Hoevenaars, Roy (2008): Strategic asset allocation \& asset liability management, Universiteit Maastricht, Maastricht.

Jacoby, Sanford M. (1997): Modern manors: welfare capitalism since the new deal. Princeton.

Jensen, Michael C. (1993): The modern industrial revolution, exit, and the failure of internal controlsystems, in: Journal of Finance 48, S. 831-880.

Kitschelt, Herbert / Wolfgang Streeck (2004): Germany: beyond the stable state, London.

Langley, Paul (2004): In the eye of the 'perfect storm': the final salary pensions crisis and financialisation of Anglo-American capitalism, in: New Political Economy 9, S. 539-558.

Langley, Paul (2006): The making of investor subjects in Anglo-American pensions, in: Environment and Planning D 24, S. 919-934.

Lash, Scott (2003): Reflexivity as non-linearity, in: Theory, Culture \& Society 20, S. 49-57.

Latour, B. (2003). Is re-modernization occurring - and if so, how to prove it?: A commentary on Ulrich Beck, in: Theory, Culture \& Society 20(2), S. 35-48.

Minns, Richard (2001): The cold war in welfare: stock markets versus pensions, London. 
Monk, Ashby H. B. (2008): The knot of contracts: the corporate geography of legacy costs, in: Economic Geography 84, S. 211-235.

Munnell, Alicia H. / Annika E. Sunden (2004): Coming up short: The challenge of 401(k) plans. Washington, D.C.

Myles, John / Paul Pierson (2001): The comparative political economy of pension reform, in: Paul Pierson (Hrsg.), The new politics of the welfare state, Oxford.

Ogawa, Naohiro / Noriyuki Takayama (2006). Demography and ageing, in: Gordon L. Clark / Alicia H. Munnell / J. Michael Orszag (Hrsg.), Oxford handbook of pensions and retirement income, Oxford.

O'Malley, Paul (2004). Risk, uncertainty, and government, London.

Paz, Octavio (1950): El laberinto de la soledad, México.

Rajan, Raghuram G. / Luigi Zingales (2001): The influence of the financial revolution on the nature of firms, in: American Economic Review, 91, S. 206-211.

Sass, Steve A. (2006): The development of employer retirement income plans: from the nineteenth century to 1980, in: Gordon L. Clark / Alicia H. Munnell / J. Michael Orszag (Hrsg.), Oxford handbook of pensions and retirement income, Oxford.

Schludi, Martin (2005). The reform of Bismarckian pension systems: a comparison of pension politics in Austria, France, Germany, Italy and Sweden, Amsterdam.

Schmähl, Winfried (2003): Private pensions as partial substitute for public pensions in Germany, in: Gordon L. Clark / Noel Whiteside (Hrsg.), Pension security in the 21st century: Redrawing the publicprivate debate, Oxford.

Schmid, Günther (2006). Social risk management through transitional labour markets, in: Socio-Economic Review 4, S. 1-33.

Shonfield, Andrew (1965): Modern capitalism: the changing balance of public and private power, London.

Strauss, Kendra (2008): Re-engaging with rationality in economic geography: behavioural approaches and the importance of context in decision-making, in: Journal of Economic Geography 8, S. 137-156.

Streeck, Wolfgang / Kathleen A. Thelen (2005): Beyond continuity: institutional change in advanced political economies, Oxford.

Thrift, Nigel J. (2005): Knowing capitalism, London.

Whiteside, Noel (2006): Adapting private pensions to public purposes: historical perspectives on the politics of reform, in: Journal of European Social Policy 16, S. 43-54.

Williamson, Oliver E. (1981): The modern corporation - origins, evolution, attributes, in: Journal of Economic Literature 19, S. 1537-1568.

World Bank (1994): Averting the old age crisis: policies to protect the old and promote growth, Oxford.

Zingales, Luigi (2000): In search of new foundations, in: Journal of Finance 55, S. 1623-1653.

Adam D. Dixon

School of Geography University of Oxford

South Parks Road

Oxford, OX1 3QY, UK

adam.dixon@ouce.ox.ac.uk 